\title{
Alternatives to Enhance Flat Slab Ductility
}

\author{
Mohamed Husain, Ahmed S. Eisa*, and Ramy Roshdy
}

\author{
(Received January 23, 2016, Accepted November 17, 2016, Published online February 28, 2017)
}

\begin{abstract}
Flat slab systems are vastly used in multi-story buildings because of their savings in story height and construction time, as well as for their flexibility in architectural remodeling. However, they frequently suffer brittle punching-shear failure around columns, especially when subjected to lateral loads. Therefore, seismic codes labeled flat slabs as non-ductile systems. This research goal is investigating some construction alternatives to enhance flat slab ductility and deformability. The alternatives are: adding different types of punching-shear reinforcement, using discreet fibers in concrete mixes, and increasing thickness of slab around columns. The experimental study included preparation and testing of seven half-scale interior slab-column connections up to failure. The first specimen is considered a reference, the second two specimens made of concrete mixes with different volumetric ratios of polymer fibers. Another three specimens reinforced with different types of punching-shear reinforcement, and the last specimen constructed with drop panel of inverted pyramidal shape. It is found that using the inverted pyramid-shape drop panel of specimen, increases the punching-shear capacity, and the initial and the post-cracking stiffnesses. The initial elastic stiffnesses are different for all specimens especially for the slab with closed stirrups where it is experienced the highest initial stiffness compared to the reference slab.
\end{abstract}

Keywords: flat slab, punching-shear, stud-rails, ductility, punching reinforcement, fibers.

\section{Introduction}

Flat slabs are preferred in multi-story construction due to its economical and architectural benefits. These benefits include; reducing the construction time and reducing story height, which results in more stories for the same building, as well as their flexibility in architectural remodeling. However, they have been discredited by many seismic codes for less ductile behavior, and poor energy absorption (IBC 2009; Eurocode 8 2004; ACI 421-1R 2008).

The capacity design method has been widely adopted by a majority of modern seismic codes, since its introduction in the New Zealand code in mid-1970s (Park and Paulay 1974; Paulay and Priestley 1992; Dovich and Wight 1996; Robertson and Johnson 2004). The method uses ductility and energy absorption characteristics of structures to dissipate large amount of the seismic imparted energy, which boosts the structural safety and reliability. It requires flexural yielding at many locations of the building and provides them with adequate ductility. At the same time prevent any possibility of brittle failure, such as, shear and bond failures.

Punching shear reinforcement is increasingly used in flat slabs because of the significant improvements introduced in strength and ductility as demonstrated in Fig. 1. Two identical

\footnotetext{
Structural Engineering Department, Faculty of Engineering, Zagazig University, Zagazig, Egypt. *Corresponding Author; E-mail: ahmedeisa@zu.edu.eg Copyright $\odot$ The Author(s) 2017. This article is published with open access at Springerlink.com
}

slab models with and without punching-shear reinforcement were tested (Ruiz and Muttoni 2010). It was observed that the strength of slab with shear reinforcement has almost double the strength of the slab without shear reinforcement; also the deformation capacity is increased more than three times. The main objective of this research is to evaluate the potential of using different alternatives for enhancing the ductility and deformability of flat slab new construction.

Hawkins (1974), Dam and Wight (2015) and Matzke et al. (2015) published a paper presenting an overview of tests performed with different punching-shear reinforcement systems such as steel heads, bent-up bars, and stirrups. During the 1980s and 1990s, Regan started his research on punching with and without shear reinforcement at the Polytechnic of Central London (Regan 1981, 1985). In the UK at the beginning of the 1990s, Chana and Desai have performed extensive experimental investigations on punching-shear tests with shear reinforcement (Chana and Desai 1992). Oliveira et al. (2000) have carried out experimental punching investigations on the effects of vertical or inclined stirrups on flat slab behavior. Carvalho (2011) also have conducted investigations on the same subject.

Another way to increase shear strength is to add fiber to concrete as shear reinforcement. Dinh et al. (2010) have tested 28 simply supported beams with 3.5 shear span/depth ratio, with different fiber volumetric ratio. They concluded that fiber concrete with appropriate fiber volumetric ratio can provide shear reinforcement to concrete beams. Meisami et al. (2013) have investigated the shear strengthening of flat slab by using fibers-reinforced concrete. In the early 1990s, a 


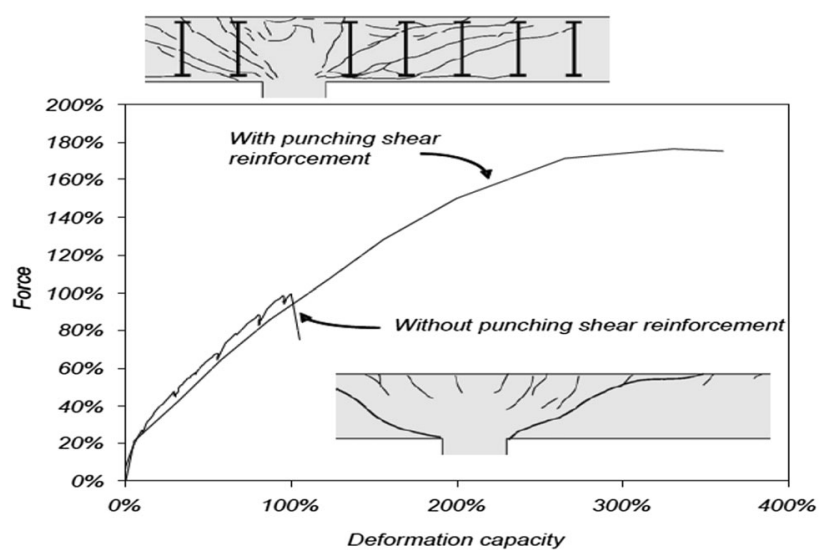

Fig. 1 Force-deformation behavior of two slab models with and without shear reinforcement (adapted from Ruiz and Muttoni et al. 2010).

team of researchers from University of California, at Berkeley, has assessed the seismic performance of 14-storynon ductile-reinforced concrete built in middle 1960s. The building was termed non-ductile, because it was designed on code provisions prior to the 1976 seismic code (Graf and Mehrain 1992). The building has survived two major seismic events-San Fernando Valley in 1971, and Loma Prieta 1989 - only by slab column framing action. It is concluded that the building exceptional behavior has to do with its inverted pyramid-shaped drop-panels. The ductility of flat plates: comparison of shear reinforcement systems have been studied (Broms 2007).

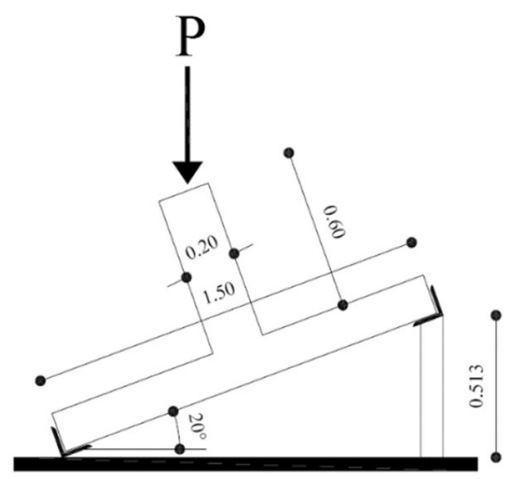

Fig. 2 Test setup and location of load on specimens.

\section{Experimental Program}

Experimental studies were designed to achieve the objectives of this research. The experimental study included construction and testing of seven half-scale interior slabcolumn connections reinforced with the same steel bars in two direction top and bottom. The first specimen is considered a reference, the second two specimens made of concrete mixes with different volumetric ratios of polymer fibers. Another three specimens reinforced with different types of punching-shear reinforcement, and the last specimen constructed with drop panel of inverted pyramidal shape. Each specimen had a square plan of side length dimension of $1500 \mathrm{~mm}$ and a central column stub of cross section $(200 \mathrm{~mm} \times 200 \mathrm{~mm})$ extending $600 \mathrm{~mm}$ beyond the top surface of the slabs. The test specimens were supported along all four edges. A concentric load was applied to the slabs through the column stub. Through the experimental program, the effects of the following parameters were investigated: (i) type of additional punching shear reinforcement; (ii) concrete with polymer fiber; (iii) slab thicknesses of 120 and $180 \mathrm{~mm}$ by adding pyramidal drop panel. All slabs were designed based on the ACI-421.IR two-way slab systems.

The slab-column connection specimens are built and tested under gravity load, and the specimens are inclined with an angle of $20^{\circ}$ that give vertical and horizontal loads on the specimens as shown in Fig. 2. The vertical load represents gravity (dead and live) loads and the horizontal load represents an equivalent static lateral load on the slab. Figure 3 shows the specimen testing setup. All slabs were reinforced with steel bars in two orthogonal directions top and bottom. Each specimen is square in plan with side-length dimension of $1500 \mathrm{~mm}$, and a central column stub extending $600 \mathrm{~mm}$ above the top surface of the slabs. The test specimens were simply supported along all four edges. A concentric load was applied to the slabs through the column stub from the top side. Through the experimental program, the effects of the following parameters were investigated: (i) type of additional punching shear reinforcing; (ii) polymer fiber; (iii) slab thickness. Table 1 summarize the details of the tested specimens.
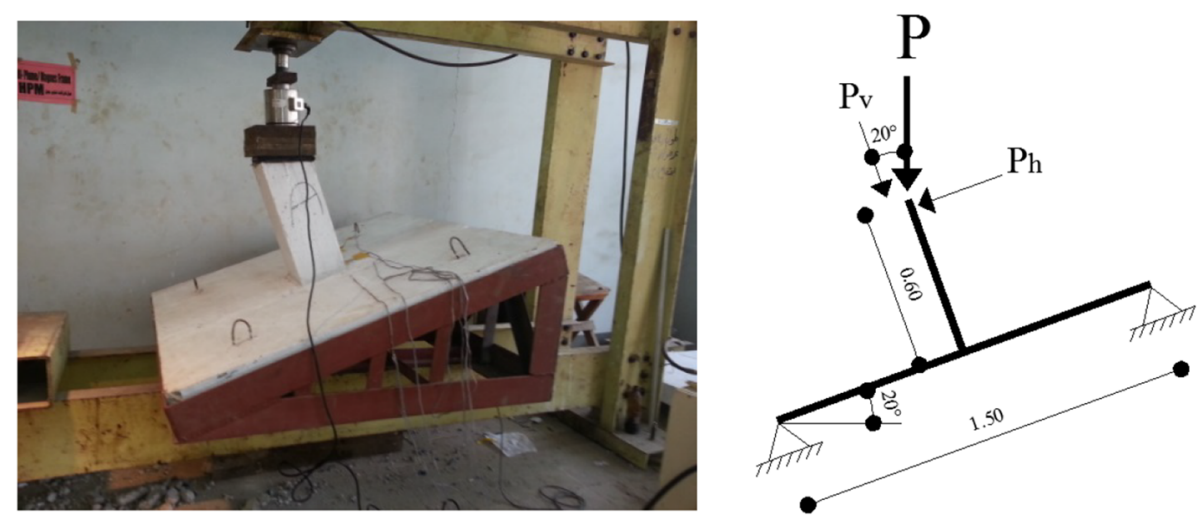

Fig. 3 Specimen on steel frame (unit: $m$ ). 
Table 1 Characteristics and dimensions of the specimens.

\begin{tabular}{|c|c|c|c|c|c|c|c|}
\hline Specimen & S1 & S2 & S3 & S4 & S5 & S6 & S7 \\
\hline Effect & Control & Fiber $0.2 \%$ & Fiber $0.3 \%$ & Stud-rails & Multi-leg stirrups & Closed stirrups & Drop panel \\
\hline Thickness (mm) & 120 & 120 & 120 & 120 & 120 & 120 & 180 \\
\hline $\begin{array}{c}\text { Effective depth } \\
(\mathrm{mm})\end{array}$ & 95 & 95 & 95 & 95 & 95 & 95 & 155 \\
\hline $\begin{array}{c}\text { Top } \\
\text { reinforcement } \\
\text { spacing }(\mathrm{mm})\end{array}$ & & & & 200 & & & \\
\hline $\begin{array}{c}\text { Bottom } \\
\text { reinforcement } \\
\text { spacing }(\mathrm{mm})\end{array}$ & & & & 167 & & & \\
\hline $\begin{array}{l}\text { Steel studs } \\
\text { spacing }(\mathrm{mm})\end{array}$ & N/A & $\mathrm{N} / \mathrm{A}$ & $\mathrm{N} / \mathrm{A}$ & 60 & N/A & N/A & N/A \\
\hline $\begin{array}{r}\text { Closed stirrups } \\
\text { spacing }(\mathrm{mm})\end{array}$ & N/A & N/A & N/A & N/A & N/A & 60 & N/A \\
\hline
\end{tabular}

Table 2 Concrete mix proportions of $1.0 \mathrm{~m}^{3}$.

\begin{tabular}{c|c|c|c|c}
\hline Ingredient & Cement $(\mathrm{kg})$ & Fine aggregate $\left(\mathrm{m}^{3}\right)$ & Coarse aggregate $\left(\mathrm{m}^{3}\right)$ & Water $(\mathrm{kg})$ \\
\hline \hline & 350 & 0.4 & 0.8 & 250 \\
\hline \multicolumn{5}{|c|}{ Different ratio of polymer fiber on specimen S2 and S3 } \\
\hline \hline \multicolumn{2}{|c|}{ Cement $(\mathrm{kg})$} & Cement per specimen $(\mathrm{kg})$ & Fiber per specimen \\
\hline S2 & 350 & 103 & $0.2 \%=206 \mathrm{~g}$ \\
\hline S3 & 350 & 103 & $0.3 \%=309 \mathrm{~g}$ \\
\hline
\end{tabular}

(a) Steel Strain gauge for all specimens

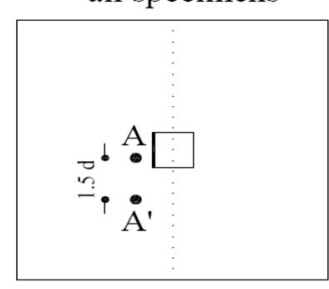

Plan

(b)

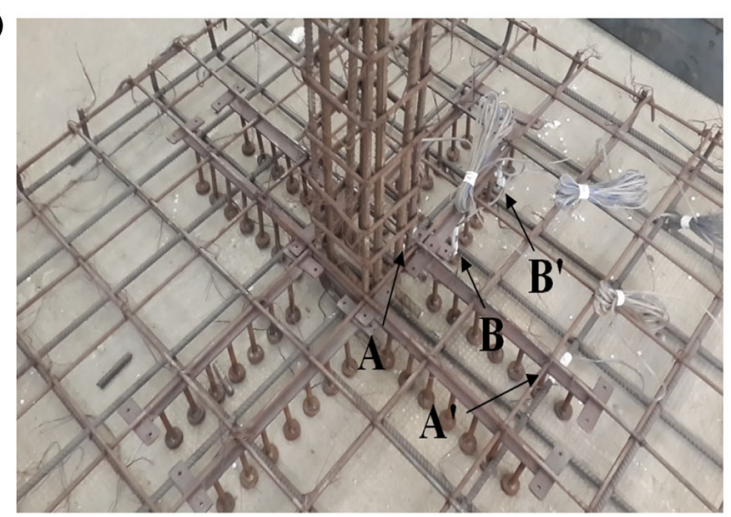

Fig. 4 a Strain gages at the top reinforcing mat (left), and at the shear reinforcement (right). b Location of $A, A^{\prime}$, $B \& B^{\prime}$.
Steel Strain gauge for specimens ( S4, S5 \& S6)

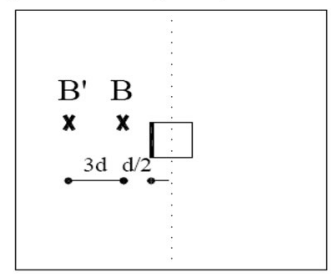

Plan

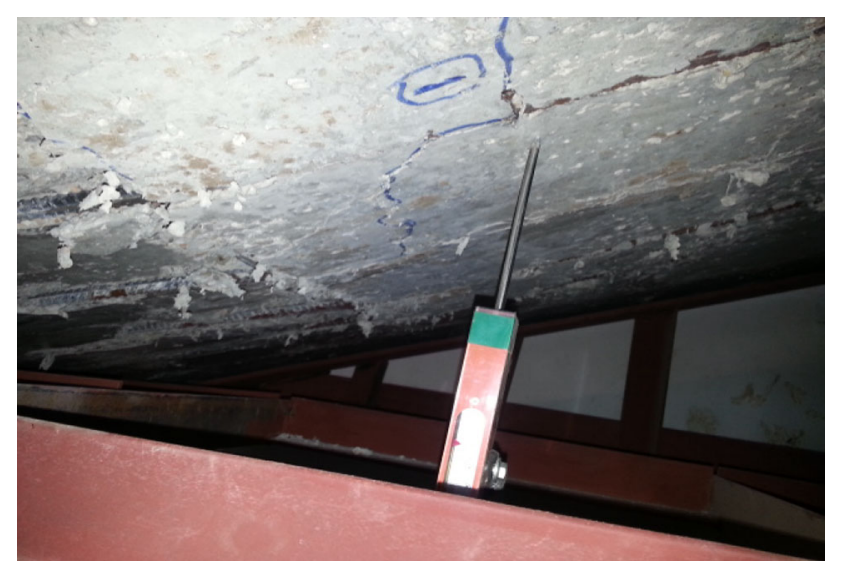

Fig. 5 Location of LVDT.

Steel studs have a head diameter of $300 \mathrm{~mm}$, shear stud's shaft diameter of $100 \mathrm{~mm}$, the steel base rail has a thickness of $60 \mathrm{~mm}$ with a length of $400 \mathrm{~mm}$ and the thickness of $10 \mathrm{~mm}$ whereas the total height is $106 \mathrm{~mm}$. The shear studs have a yield strength of $360 \mathrm{~N} / \mathrm{mm}^{2}$. The multiple-leg stirrups arranged every $60 \mathrm{~mm}$, and the height of the stirrup is $100 \mathrm{~mm}$ and the diameter is $6 \mathrm{~mm}$. The closed stirrups used in slab S6, arranged every $60 \mathrm{~mm}$ with a diameter of $6 \mathrm{~mm}$. All slabs have $5 \phi 8 / \mathrm{m}$ as a top reinforcement and $6 \phi 12 / \mathrm{m}$ as 


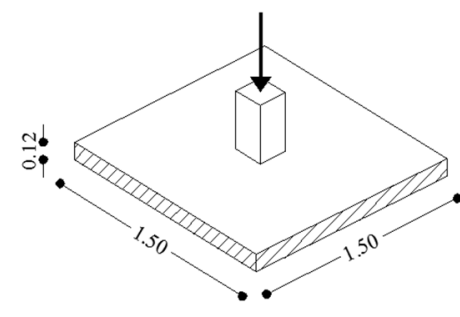

Specimen S1

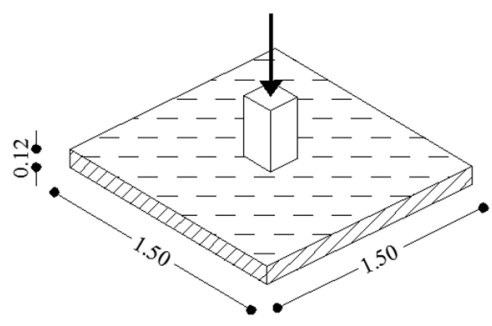

Specimen S2, and S3

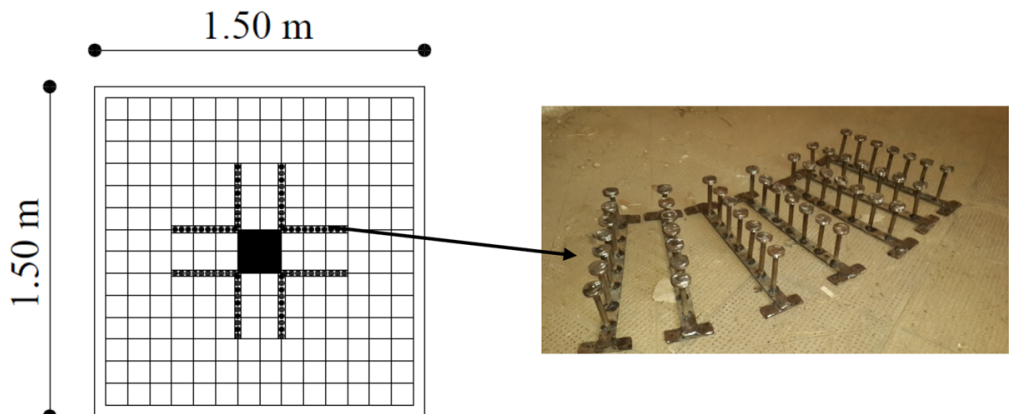

Specimen S4

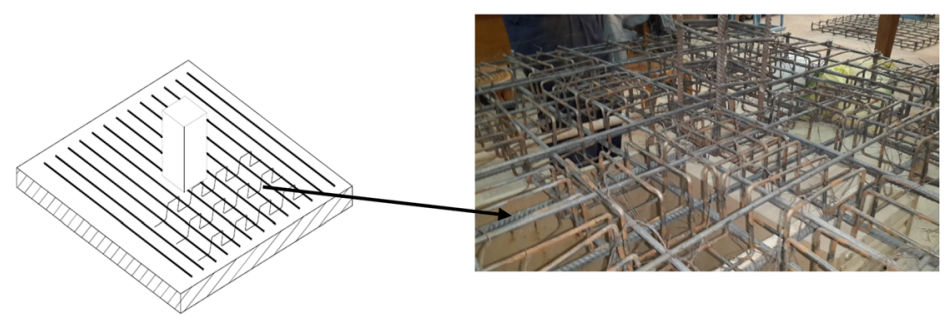

Specimen S5

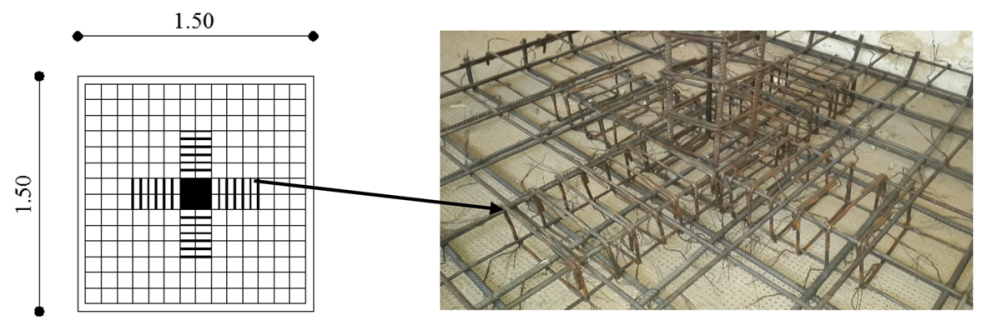

Plan

Specimen S6

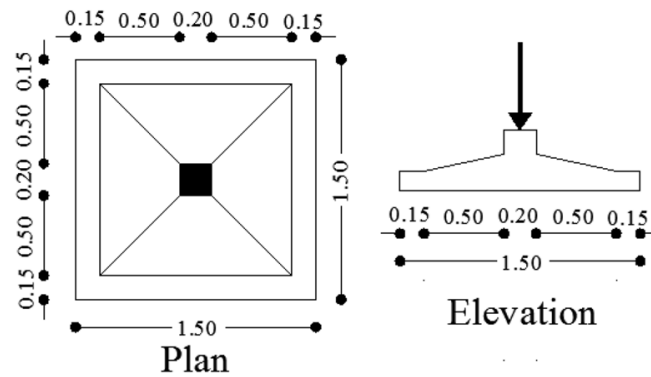

Specimen S7

Fig. 6 Different specimen configurations (unit: m) 
Table 3 Specimen's cracking load, failure load, and deflection.

\begin{tabular}{c|c|c|c|c}
\hline Specimens & Cracking load $(\mathrm{kN})$ & Failure load $(\mathrm{kN})$ & Deflection at failure (mm) & Failure mode \\
\hline \hline S1 & 20 & 130 & 13 & Brittle \\
\hline S2 & 22 & 135 & 15.5 & Brittle \\
\hline S3 & 23 & 141 & 17 & Brittle \\
\hline S4 & 25 & 200 & 22 & Ductile \\
\hline S5 & 27 & 220 & 35 & Ductile \\
\hline S6 & 30 & 244 & - & Ductile \\
\hline S7 & 35 & 300 & N/A \\
\hline
\end{tabular}

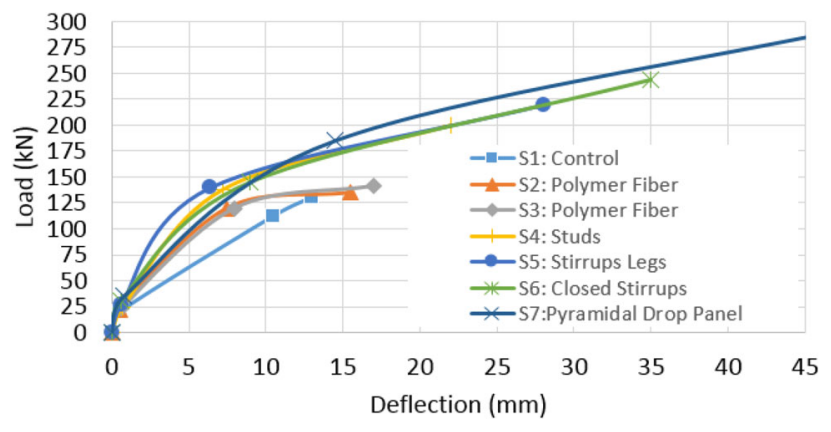

Fig. 7 Load-deflection relations of tested specimens.

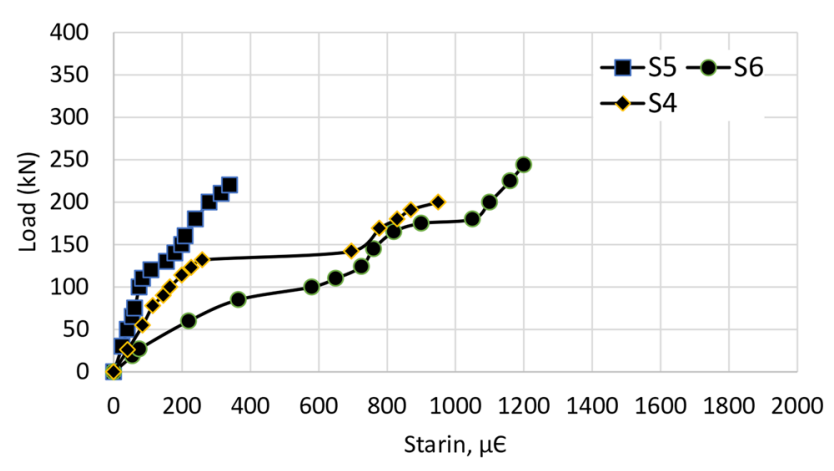

Fig. 8 Strain of shear reinforcement in slabs S4, S5, and S6.

a bottom reinforcement. The shear studs and stirrups are arranged at a distance of $0.5 \mathrm{~d}$ from the column face.

\subsection{Material Properties}

All concrete mixtures were normal weight concrete and tested for a 28-day's compressive strength with an average of $\left(310 \mathrm{~kg} / \mathrm{cm}^{2}\right)$. Coarse aggregate in the concrete mixture consisted of crushed basalt rock from Ataqa area in Egypt, the mix proportions of concrete for $1.0 \mathrm{~m}^{3}$ of concrete is shown in Table 2. Polymer fiber concrete used for specimens $\mathrm{S} 2$ and S3 with different ratio are shown in Table 2.

The characteristic yield strength of steel bars was $360 \mathrm{MPa}$ and the mean yield strength of the steel bars was $f_{y}=382 \mathrm{MPa}$ (obtained from direct tension tests on three specimens). The ultimate strength of the steel bars was $f_{u}=532 \mathrm{MPa}$ and the average uniform elongation of bars at $f_{u}$ was $\varepsilon_{u}=11 \%$.

\subsection{Test Setup}

A vertically oriented hydraulic actuator, connected to a steel reaction frame, is used for application of the load to the slab specimens that shown in Fig. 3. This setup helps to subject the connection to horizontal and vertical loads to create unbalanced moment typical of lateral loads.

The installation of strain gages for concrete structures presents several unique challenges to the installer, whether measurements are made on the concrete surface or within the concrete, or on reinforcement bars within the structure. Figures 4 and 5 show the location of stain gages installed in the present study. The deflection of the test specimens was captured with linear variable differential transformers (LVDT). Figure 6 shows the specimen details for all the tested slabs.

\section{Results and Discussion}

\subsection{Load Deflection}

The typical load-deflection behavior of all specimens was linear up to the yield load, when the yield of the longitudinal steel reinforcement was reached; the behavior changed to nonlinear up to failure. The cracking failure loads and corresponding vertical deflections for all tested specimens are listed in Table 3.

Load-deflection curves of all specimens S1, S2, S3, S4, S5, S6 and S7, respectively are presented in Fig. 7 and Table 3. The control slab is failed at an ultimate load of $130 \mathrm{kN}$ with a corresponding deflection of $13 \mathrm{~mm}$. The addition of fiber to the concrete mixtures has a noticeable effect on the ultimate load, where the 0.2 and $0.3 \%$ of fiber increased the ultimate load by 3.8 and $8.4 \%$, respectively. The ultimate deflection increased by 19.2 and $30.7 \%$ for the 0.2 and $0.3 \%$ fiber volume, and compared to the control deflection. Using steel studs around the slab-column connection enhanced the ultimate load and deflection significantly by 53.8 and $69.23 \%$, respectively compared to the control specimen. A similar behavior was noticed when using the stirrup legs as well. An outperformed behavior was obtained when the slab-column connection was reinforced by closed stirrups, where the ultimate load and deflection increased by 87.7 , and $269 \%$ respectively. Finally as it was expected, the pyramidal drop panel shape increased the 
ultimate load by $230 \%$ compared to the control specimens (Fig. 8).

\subsection{Crack Pattern}

The cracking load $P_{c r}$ and the mid-span deflection $\Delta$ corresponding to the cracking load of the specimens are given in Table 4. In regard to the $P_{c r}$ values reported in Table 4, it is concluded that the cracking load of the control slab without fibers, $\mathrm{S} 1$ is around $9-10 \%$ less than the cracking load of the slabs with fibers. This can be attributed partly to shrinkage induced cracks in the non-symmetrically reinforced sections; however, the uniform distribution of fibers in slabs S2 and S3 can lessen the shrinkage induced cracks.

The initiation and development of first cracking at midpoint of the control slab and the slabs with fibers of 0.2 and $0.3 \%$ by volume ( $\mathrm{S} 2$ and $\mathrm{S} 3$ ) took place at deflection $\Delta_{c r}$ of $0.5-0.6 \mathrm{~mm}$, respectively (Table 4 ). The development of cracks at mid-span is associated with a small reduction in the load and a load drop followed the onset of first cracking is a characteristic of reinforced concrete members tested. The cracking load increased with the addition of the studs, stirrup legs and the closed stirrups by 25,35 , and $50 \%$, respectively compared to the control specimen. It was seen that the maximum cracking load recorded from all the specimens tested was related to the addition if the pyramidal drop panel shape, where the cracking load reached $35 \mathrm{kN}$ by an increase equal $75 \%$ compared to the control slab with and enhancement of the cracking deflection of $60 \%$. The crack patterns of specimens S1, S4, and S5 are shown in Fig. 9. Specimen S7 did not reach failure due to lab limitations (available load capacity $=300 \mathrm{kN}$ ).

For measured shear stress (at maximum applied load $P_{u}$ recorded during the tests). The shear stress for all concrete slabs was predicted by the shear equation provided by ACI 421.1R as in the following:

$$
v_{\mathrm{u}}=\frac{V_{u}}{A_{c}}+\frac{\gamma_{v x} M_{u x} y}{J_{c}} .
$$

$V_{u}$ is the factored shear force and $M_{u x}$ is the unbalanced moment, $A_{c}$ is the concrete area resisting shear, $J_{c}$ is the polar moment of inertia. $\mathrm{Y}$ is the location where the maximum shear stress is calculated. More details could be found in the ACI 421.1R.

While the nominal shear strength in slabs S1, and S7, where shear reinforcement is not provided, were taken the smallest value of Eqs. 4-7b, 4-8b, and 4-9b in ACI421.1R. The shear strength of slabs with stirrups (S5 and S6) is calculated based on Eq. 4-11 in ACI 421.1R, and finally the
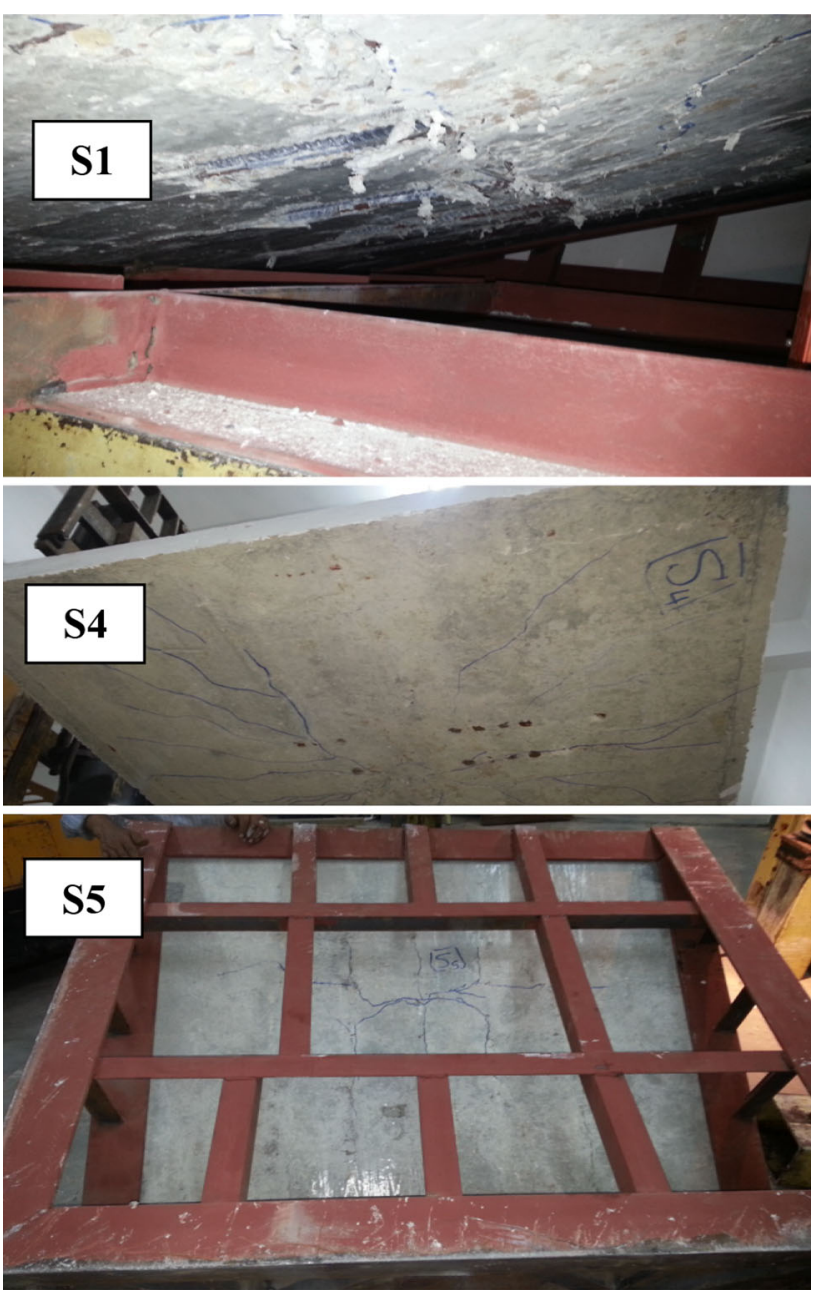

Fig. 9 Cracks patterns of specimens S1, S4, and S5.

Table 4 Load deflection at different load stages and shear strength.

\begin{tabular}{|c|c|c|c|c|c|c|c|c|}
\hline Slabs & $\mathrm{P}_{\mathrm{cr}}(\mathrm{kN})$ & $\Delta_{\mathrm{cr}}(\mathrm{mm})$ & $\mathrm{P}_{\mathrm{y}}(\mathrm{kN})$ & $\Delta_{\mathrm{y}}(\mathrm{mm})$ & $\mathrm{P}_{\mathrm{u}}(\mathrm{kN})$ & $\Delta_{\mathrm{u}}(\mathrm{mm})$ & $\begin{array}{c}\mathrm{V}_{\mathrm{u}} \text { (measured } \\
\text { shear strength) } \\
\text { ACI 421-1R } \\
\left(\mathrm{N} / \mathrm{mm}^{2}\right)\end{array}$ & $\begin{array}{c}\mathrm{V}_{\mathrm{n}} \text { (nominal } \\
\text { shear strength) } \\
\text { ACI 421-1R } \\
\left(\mathrm{N} / \mathrm{mm}^{2}\right)\end{array}$ \\
\hline $\mathrm{S} 1$ & 20 & 0.5 & 112 & 10.5 & 130 & 13 & 3.00 & 1.83 \\
\hline $\mathrm{S} 2$ & 22 & 0.5 & 120 & 7.5 & 135 & 15.5 & N/A & $\mathrm{N} / \mathrm{A}$ \\
\hline S4 & 25 & 0.7 & 138 & 7.2 & 200 & 22 & 3.69 & 4.16 \\
\hline S5 & 27 & 0.6 & 140 & 6.4 & 220 & 28 & 5.08 & 1.1 \\
\hline S6 & 30 & 0.6 & 145 & 9 & 244 & 35 & 5.63 & 1.57 \\
\hline S7 & 35 & 0.8 & 185 & 14.5 & 300 & - & 2.97 & 1.83 \\
\hline
\end{tabular}


Table 5 Ductility ratio of all specimens.

\begin{tabular}{c|c|c|c}
\hline Slab & $\Delta_{y}(\mathrm{~mm})$ & $\Delta_{u}(\mathrm{~mm})$ & $\mu_{\Delta}=\Delta_{u} / \Delta_{y}$ \\
\hline S1 & 10.5 & 13 & 1.238 \\
\hline S2 & 7.5 & 15.5 & 2.067 \\
\hline S3 & 8 & 17 & 2.125 \\
\hline S4 & 7.2 & 22 & 3.056 \\
\hline S5 & 6.4 & 28 & 4.375 \\
\hline S6 & 9 & 35 & 3.888 \\
\hline S7 & 14.5 & - & N/A \\
\hline
\end{tabular}

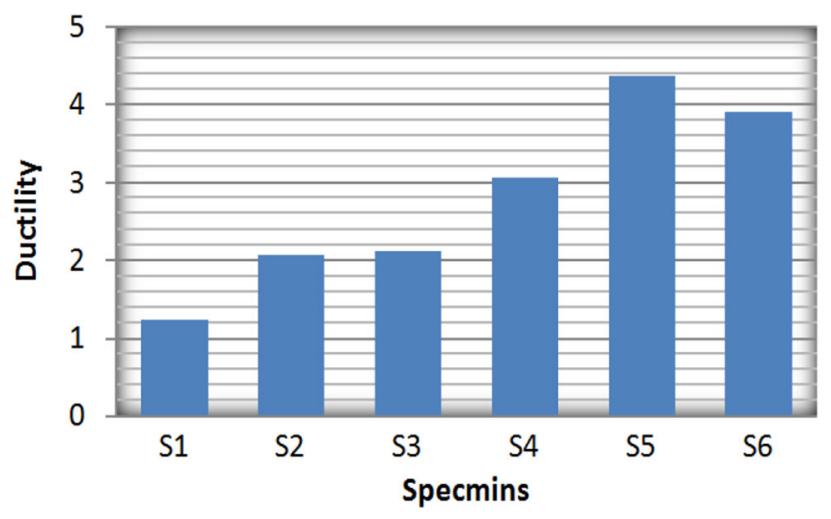

Fig. 10 Ductility ratio of specimens.

nominal shear strength of slab S4 is calculated based on Sec. 4.3 .3 in the same document.

\subsubsection{Example Slab S4 (Shear Studs Provided)}

$$
\begin{aligned}
v_{u}(\text { Eq. } 1)= & \frac{200,000 \cos 20}{2(295 \times 95)+2(295+95)} \\
& +\frac{0.4 \times 200,000 \sin 20 \times 600 \times 295 / 2}{\frac{95^{3} \times 295}{6}+\frac{295^{3} \times 95}{6}+\frac{295 \times 295^{2} \times 95}{2}} \\
= & 4.61 \mathrm{~N} / \mathrm{mm}^{2}
\end{aligned}
$$

Column dimensions $(\mathrm{c})=200 \times 200 \mathrm{~mm}^{2}$.

The critical section perimeter $=\mathrm{c}+\mathrm{d}=200+95=$ $295 \mathrm{~mm}$.

Column height $=600 \mathrm{~mm}$.

$P_{u}=200,000 \mathrm{~N}$.

The nominal shear strength is calculated based on the following:

$$
\begin{aligned}
v_{c} & =\frac{\sqrt{f_{c}^{\prime}}}{4}=1.4 \mathrm{~N} / \mathrm{mm}^{2} \\
v_{s} & =\frac{A_{v}}{S} \times \frac{f_{y}}{b_{0}}=\frac{8 \times 78.5 \times 360}{60 \times(2 \times 295+2 \times 295)} \\
& =2.79 \mathrm{~N} / \mathrm{mm}^{2}
\end{aligned}
$$$$
v_{n}=v_{c}+v_{s}=1.4+2.79=4.16 \mathrm{~N} / \mathrm{mm}^{2} .
$$

In Table 4; $P_{c r}$ and $\Delta_{c r}$ : load and deflection of the specimen at first crack, $P_{y}$ and $\Delta_{y}$ : load and deflection of the

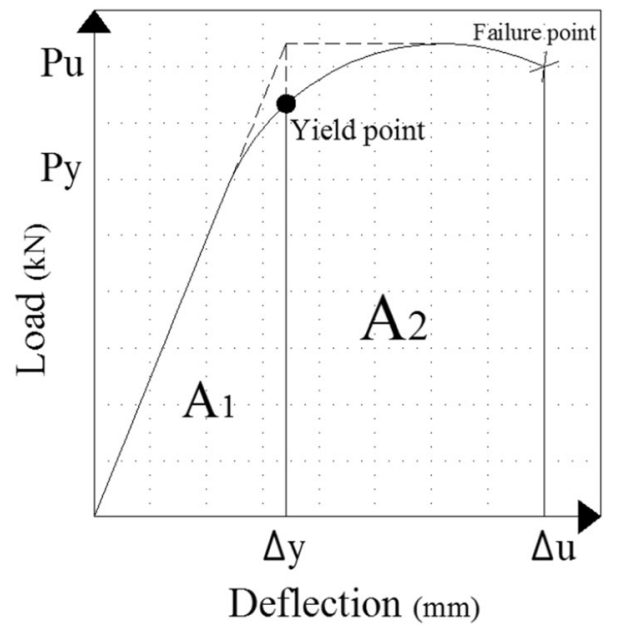

Fig. 11 Area $\mathrm{A} 1$ and $\mathrm{A} 2$.

specimen at yield point, $P_{u}$ and $\Delta_{u}$ : load and deflection of the specimen at yield point at failure. The following equations are used to define the cracking and yield points from the steel strain readings.

$$
\begin{aligned}
& \varepsilon_{\text {Concrete }}=\varepsilon_{\text {Steel }}=\frac{\delta}{E_{\text {Steel }}}=\frac{n \times f_{\text {ctr }}}{E_{\text {Steel }}} \\
& \varepsilon_{\text {Steel }}=\frac{10 \times 1.9 \sqrt{320}}{2 \times 10^{6}}=150 \times 10^{-6}=150 \mu \varepsilon \\
& \varepsilon_{y}=\frac{\delta_{y}}{E_{\text {Steel }}}=\frac{3600}{2 \times 10^{6}}=1800 \times 10^{-6}=1800 \mu \varepsilon
\end{aligned}
$$

Table 4 shows the shear strength resisted by concrete for all the slabs except S2, and S3. The predicted values based on the ACI 421-1R (2008) and it is noticed that the percentages of actual/predicted shear strength are varied. The closest prediction was for slab S7 where the actual-topredicted shear strength was 0.96 and the worst prediction was for slab S4 where the percentage of difference was 0.65 .

\subsection{Slabs Ductility}

The ultimate load capacity, $P_{u}$, and the deflection value at ultimate load level, $\Delta_{u}$, and the ductility ratio, $\mu_{\Delta}$ (measure 
Table 6 EAl and stiffness of all slab specimens.

\begin{tabular}{c|c|c|c|c|c|c}
\hline Slab & $A 1$ & $A 2$ & $A 1+A 2$ & $E A I$ & $K_{i}$ & $K_{s}$ \\
\hline \hline S1 & 5.88 & 3.25 & 9.13 & 1.55 & 40.0 & 10.7 \\
\hline S2 & 4.5 & 10.8 & 15.3 & 3.40 & 44.0 & 16.0 \\
\hline S3 & 4.8 & 12.69 & 17.49 & 3.64 & 38.3 & 15.0 \\
\hline S4 & 4.97 & 29.6 & 34.57 & 6.96 & 35.7 & 19.2 \\
\hline S5 & 4.48 & 47.52 & 52 & 11.61 & 45.0 & 21.9 \\
\hline S6 & 6.53 & 63.44 & 69.97 & 10.72 & 50.0 & 16.1 \\
\hline S7 & 13.41 & NA & NA & NA & 43.8 & 12.8 \\
\hline
\end{tabular}

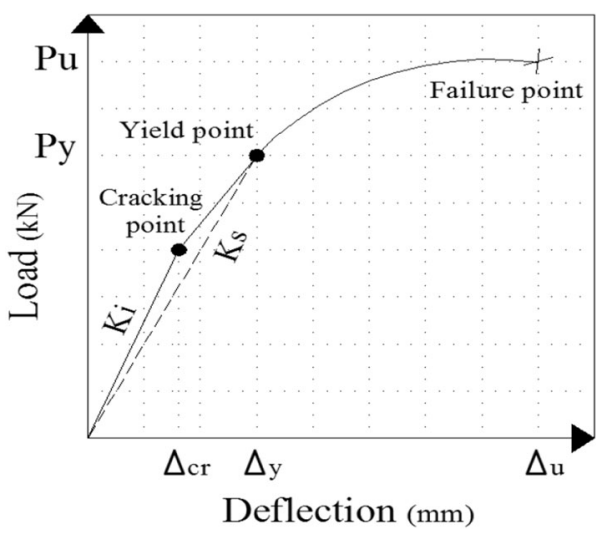

Fig. 12 Definition of $K_{i}$ and $K_{s}$.

of ductility) are listed in Table 5. Specimen S2 and S3 failed in a more ductile manner than specimen S1, suggesting that the fibers added to the concrete mixtures enhanced the ductility by an average of $66 \%$ relative to the control slab and thus provided ductility to the reinforced concrete slab column connections. In terms of ductility provided by the shear studs layout improved the ductility by a significant percentage $(246 \%)$ compared to the control slab. Both the shear legs and the closed stirrups provided outperformance of ductility where it was observed to be 353 , and $314 \%$ respectively.

Figure 10 shows ultimate load and deflection of the specimens, it shows that S7 exhibit higher strength with no signs of near failure, compared with all specimens. Also the bar chart for the ductility for all specimens was observed that S5 and S6 exhibited higher ductility compared with S4 that because the large number of stirrup legs in S5, and confinement of concrete of the closed stirrups S6.

\section{Energy Absorption Index (EAI)}

Previous research on the performance of buildings during severe earthquakes indicated that energy dissipation plays a very important role in protecting buildings from collapse. The EAI is defined as the ratio of the total area under loaddeflection curve to that under the elastic part only as calculated in Eq. 2 (Fig. 11):

$$
E A I=\frac{A_{1}+A_{2}}{A_{1}}
$$

The EAI is calculated and listed in Table 6, it shows that specimens S5 has the highest energy absorption, about 7.5 times of the value of the control specimen S1. Specimens S4 and S6 exhibited energy absorption about 3.8, and 7 times of the value of $\mathrm{S} 1$.

\subsection{Slab Stiffness}

Two different stiffnesses the initial stiffness $K_{i}$, and the post secant stiffness $K_{s}$ were obtained from experimental data by using Eq. 3, and listed in Table 6 (Fig. 12).

$$
K_{i}=\frac{P_{c r}}{\Delta_{c r}} \quad \text { and } \quad K_{s}=\frac{P_{y}}{\Delta_{y}}
$$

Table 6 shows the initial stiffness for all specimens. It is observed that all specimens have almost the same elastic stiffness except S5 (due to stirrups legs) and S7 (due to the larger depth).

\section{Conclusions}

From this study the following conclusions can be drawn:

1. The addition of the pyramid-shaped drop panel in specimen (S7), has led to the increased strength, initial stiffness, and secant stiffness.

2. The initial stiffness of specimens reinforced with studrail have increased by about $12.5 \%$ compared to the control slab.

3. The secant stiffness for specimens made of fiber concrete S2, and S3 have increased by about 49.5 and $40 \%$ relative to the control specimens.

4. In terms of ductility provided by the shear studs layout improved the ductility by a significant percentage $(246 \%)$ compared to the control slab. Both the shear legs and the closed stirrups provided outperformance of ductility where it was observed to be 353 , and $314 \%$ respectively.

5. Specimens S5 has the highest energy absorption index (energy dissipation), about 7.5 times of the value of the 
control specimen S1. Specimens S4 and S6 exhibited energy absorption about 3.8, and 7 times of the value of S1.

6. Finally, the following conclusions on ductility shall be emphasized: The use of fiber concrete has increased the post-crack stiffness only with no ductility, deformability, or energy dissipation enhancements.

7. Good ductility enhancements obtained by using multileg and closed stirrups as punching-shear reinforcements, even better than the ductility of the famous studrail reinforcement.

\section{Open Access}

This article is distributed under the terms of the Creative Commons Attribution 4.0 International License (http:/ /creativecommons.org/licenses/by/4.0/), which permits unrestricted use, distribution, and reproduction in any medium, provided you give appropriate credit to the original author(s) and the source, provide a link to the Creative Commons license, and indicate if changes were made.

\section{References}

ACI 421-1R. (2008). Guide to shear reinforcement for slabs. Farmington Hills, MI: American Concrete Institute.

Broms, C. E. (2007). Ductility of flat plates: Comparison of shear reinforcement systems. ACI Structural Journal, 104(6), 703.

Carvalho, G. (2011). Análise Sísmica de Edificios de Betão Armado Estudo de Alternativas de Modelação Análise Não-Linear. Master's thesis, Instituto Superior Técnico, Universidade Técnica de Lisboa, Portugal.

Chana, P. S., \& Desai, S. B. (1992). Design of shear reinforments against punching. The Structural Engineer, 70(5), $159-164$.

Dam, T. X., \& Wight, J. K. (2015). Flexurally-triggered punching shear failure of reinforced concrete slab-column connections reinforced with headed shear studs arranged in orthogonal and radial layout. Engineering Structures, 110, 258-268.

Dinh, H. H., Montesinos, G. J., \& Wight, J. K. (2010). Shear behavior of steel fiber-reinforced concrete beams without stirrups reinforcements. ACI Structural Journal, 107(5), 597-606.

Dovich, L., \& Wight, J. K. (1996). Lateral response of older flat slab frames and the economic effect on retrofit. Earthquake Spectra, 12(4), 667-691.

Eurocode 8-EC8. (2004). Design provision for earthquake resistance of structures. EN 1998-1-1.

Graf, W. P., \& Mehrain, M. (1992). Analysis and testing of a flat slab concrete building. In World conference on earthquake engineering, Rotter Dam, ISBN90 54100605.

Hawkins, N. M. (1974). Shear strength of slabs with shear reinforcement. ACI Publication, 42(34), 785-815.

ICC, International Building Code-IBC. (2009). Birmingham, AL: International Code Council.

Matzke, E. M., Lequesne, R. D., Parra-Montesinos, G. J., \& Shield, C. K. (2015). Behavior of biaxially loaded slabcolumn connections with shear studs. ACI Structural Journal, 112(3), 335.

Meisami, M., Mostofinejad, D., \& Nakamura, H. (2013). Punching shear strengthening of two-way flat slabs with CFRP grids. Journal of Composites for Construction, 18(2). doi:10.1061/(ASCE)CC.1943-5614.0000443.

Oliveira, D. R., Melo, G. S., \& Regan, P. E. (2000). Punching strengths of flat plates with vertical or inclined stirrups. $A C I$ Structural Journal, 97(3), 485-491.

Park, R., \& Paulay, T. (1974). Reinforced concrete structures. New York: Wiley.

Paulay, T., \& Priestley, M. J. N. (1992). Seismic design of reinforced concrete and masonry buildings. New York: Wiley.

Regan, P. E. (1981). Behavior of reinforced concrete flat slabs. Technical Report 89, Construction Industry Research and Information Association (CIRIA), London.

Regan, P. E., \& Bræstrup, M. W. (1985). Punching shear in reinforced concrete. Comité Euro-International du Béton, Bulletin d'Information, No. 168.

Robertson, I. N., \& Johnson, G. P. (2004). Non-ductile slabcolumn connections subjected to cyclic lateral loading. In 13th World conference on earthquake engineering, Vancouver, BC.

Ruiz, M. F. \& Muttoni, A. (2010). Performance and design of punching shear reinforcing systems. In 3rd fib international congress, Maryland. 